\title{
18. OCCURRENCE OF BOLBOFORMA (ALGAE, CHRYSOPHYTA) IN THE SUBANTARCTIC (ATLANTIC) PALEOGENE 1
}

\author{
Dorothee Spiegler ${ }^{2}$
}

\begin{abstract}
Sediments from ODP Holes 699A, 700B, 702B, 703A, and 704B were studied in order to determine and to understand the distribution of Bolboforma. Ten Bolboforma taxa were detected in the 294 samples analyzed. Based on Bolboforma species, a zonation correlated to the paleomagnetic record is proposed for the late middle Eocene to early Oligocene. Four biozones can be defined: the Bolboforma indistincta Zone for the lower part of the upper middle Eocene sequence, the Bolboforma eocena Zone for the upper part of the upper middle Eocene to upper Eocene, the Bolboforma geomaris Zone for the upper Eocene, and the Bolboforma latdorfensis Zone for the lower Oligocene sequence.
\end{abstract}

\section{INTRODUCTION}

During Ocean Drilling Program (ODP) Leg 114, 12 holes were drilled at seven sites along a west to east transect across the subantarctic region of the Atlantic Ocean (Fig. 1), providing an unique opportunity for obtaining long, undisturbed, continuous sequences of Paleogene sediments.

Leg 114 cores retrieved a complete high-quality data base with the aim of producing a biostratigraphic framework of planktonic fossils, such as planktonic foraminifers, calcareous nannofossils, diatoms, radiolarians, and silicoflagellates, that will provide an excellent Paleogene stratigraphic record for the southern part of the Atlantic Ocean. Well-preserved specimens of Bolboforma occur in many of the Paleogene samples from these core sites. These microfossils are abundant in the upper middle Eocene and upper Eocene sequences. Bolboforma are rare in Oligocene sediments, and they are absent in sequences older than middle Eocene.

Bolboforma are believed to belong to the Protophyta and are informally grouped within the Chrysophyceae (Algae) as the family Bolboformaceae Spiegler, 1987 (Spiegler, 1987). Bolboforma exhibit a generally spheroid shape, similar to that of the benthic foraminifer Lagena. In contrast to foraminifers, however, Bolboforma are generally composed of monocrystalline, low-magnesium calcite. Usually Bolboforma are single chambered, but a few are uniserial double chambered (Daniels et al., 1981), and some encapsulated specimens of different species have been detected (Poag and Karowe, 1986, 1987; Spiegler, 1987).

Bolboforma are a proven stratigraphic tool both in Neogene and Paleogene sediments. Their distribution in Neogene samples from the North Atlantic realm has been documented (Echols, 1985; McNeil, 1988; Müller et al., 1984; Murray, 1979, 1984, 1987; Poag and Karowe, 1986, 1987; Qvale and Spiegler, 1989; Spiegler, 1987). Rögl and Hochuli (1976) and Gazdzicki and Wrona (1986) described Bolboforma in lower Miocene sediments drilled on the continental rise of the antarctic Bellinghausen Sea. Knowledge of distribution patterns of Bolboforma in Paleogene sequences is still very

\footnotetext{
${ }^{1}$ Ciesielski, P. F., Kristoffersen, Y., et al., 1991. Proc. ODP, Sci. Results, 114: College Station, TX (Ocean Drilling Program).

${ }^{2}$ GEOMAR Research Center for Marine Geoscience at the ChristianAlbrechts-University, Wischhofstraße 1-3, Building 4, D-2300 Kiel 14, FRG.
}

limited. Up to now, the oldest known occurrence of Bolboforma extends to the middle part of the middle Eocene $(\sim 44$ Ma) (Kennett and Kennett, in press). Poag and Karowe (1986, 1987) documented Bolboforma in upper Eocene sequences of Deep Sea Drilling Project (DSDP) Leg 95 (Site 612, in the western North Atlantic and Gulf Coast) and in upper Eocene sediments of DSDP Leg 90 (Site 592, in the western South Pacific). Pallant and Kaminski (1989) described the occurrence of Bolboforma in upper Eocene sediments of ODP Leg 105, from Site 647 in the Labrador Sea. Bolboforma of Oligocene age are more common than Eocene forms. For instance, Bolboforma are documented from outcrops in Mississippi and Virginia (Tappan, 1980; Poag and Karowe, 1986, 1987) and in United States Atlantic margin sites (Poag and Karowe, 1986, 1987) and have also been observed in the Oligocene of northwest Germany (Daniels and Spiegler, 1974). In this study Bolboforma are documented from strata of middle Eocene to early Oligocene age.

\section{MATERIAL AND METHODS}

I report results from analyses of Holes 699A, 700B, 702B, $703 \mathrm{~A}$, and 704B. Hole 698A contains no Bolboforma. Hole $701 \mathrm{C}$ was not analyzed. In general, I investigated the same samples that Nocchi et al. (this volume) used to study Paleogene planktonic foraminifers (i.e., one sample per section; 294 samples in the drilled Paleogene sediment). Samples of about $20 \mathrm{~cm}^{3}$ were prepared by drying and soaking in water before being washed through a $40-\mu \mathrm{m}$ screen. The analyses were carried out on the fraction $>40$ $\mathrm{mm}$. Scanning electron microscopy (SEM) was used for detailed taxonomic studies. The 10 species observed in the Leg 114 material are described briefly in the captions of Plates 1 and 2. The full systematic descriptions are given in Spiegler and Daniels (in press).

\section{RESULTS}

\section{Site 699}

Hole $699 \mathrm{~A}$ is located on the northeastern slope of the Northeast Georgia Rise (Fig. 1 and Table 1). One sample per section (140 samples) was analyzed in the interval between 80.56 and $439.75 \mathrm{~m}$ below seafloor (mbsf). Down to 250.54 mbsf the samples are barren of Bolboforma. The sequence between 251.78 to 285.28 mbsf contains Bolboforma pustula 


\section{SPIEGLER}

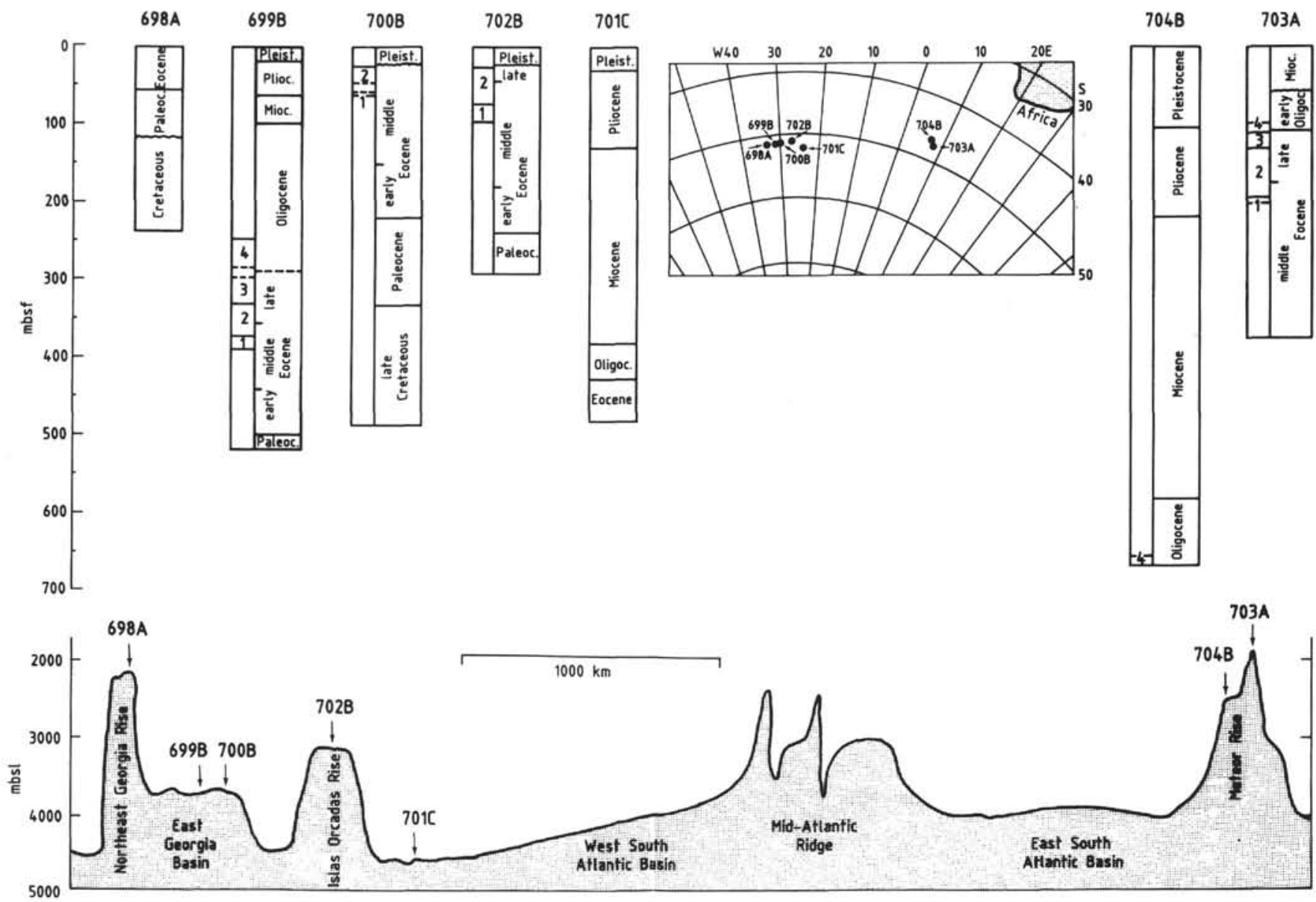

Figure 1. Locations and cross sections of Leg 114 sites. The composite columns for each site show age, stratigraphic thickness, and Bolboforma zones: $1=B$. indistincta Zone, $2=B$. eocena Zone, $3=B$. geomaris Zone, $4=B$. latdorfensis Zone. Hole $698 \mathrm{~A}$ contains no Bolboforma and Hole $701 C$ was not analyzed. (Modified from Leg 114 Scientific Drilling Party, 1987).

Table 1. Location and water depth of ODP Leg 114 holes containing Bolboforma in Paleogene sediments.

\begin{tabular}{lccc}
\hline Hole & $\begin{array}{c}\text { Latitude } \\
(\mathrm{S})\end{array}$ & Longitude (W) & Water depth (m) \\
\hline 699A & $51^{\circ} 32.537^{\prime}$ & $30^{\circ} 40.619^{\prime}$ & 3707.5 \\
$700 \mathrm{~B}$ & $51^{\circ} 31.992^{\prime}$ & $30^{\circ} 16.697^{\prime}$ & 3597.9 \\
$702 \mathrm{~B}$ & $50^{\circ} 56.786^{\prime}$ & $26^{\circ} 22.117^{\prime}$ & 3083.7 \\
$703 \mathrm{~A}$ & $47^{\circ} 03.042^{\prime}$ & $07^{\circ} 53.679^{\prime} \mathrm{E}$ & 1806.6 \\
$704 \mathrm{~B}$ & $46^{\circ} 52.785^{\prime}$ & $07^{\circ} 25.231^{\prime} \mathrm{E}$ & 2530.8 \\
\hline
\end{tabular}

and Bolboforma latdorfensis, forms that are typically Oligocene in age (Spiegler and Daniels, in press). The strata from 286.78 to 296.64 mbsf are again barren of Bolboforma. Beneath $297.80 \mathrm{mbsf}$ and down to $389.56 \mathrm{mbsf}, 75 \%$ of the examined samples contains Bolboforma taxa. Abundant Bolboforma occur between 329.45 and 371.26 mbsf. The last occurrences (LO) of Bolboforma geomaris and Bolboforma lamari in Sample 114-699A-33X-1, 70-74 cm, are notable. The LO of Bolboforma eocena ${ }^{3}$ in Sample 114-699A-37X-1, 124$126 \mathrm{~cm}$, and the first occurrence (FO) of the same species in Sample 114-699A-40X-CC are important events for the zona-

\footnotetext{
${ }^{3}$ Kennett and Kennett (in press) described Bolboforma antarctica as a new species that is equivalent to $B$. eocena (Spiegler, in press). B. eocena thus becomes synonymous with $B$. antarctica. Therefore, the species name $B$. eocena as well as the $B$. eocena Zone name are replaced by $B$. antarctica.
}

tion of the Eocene sequences by means of Bolboforma in the Leg 114 holes. The samples from 303.80 to 389.56 mbsf contain sporadic Bolboforma indistincta. From 391.22 to 439.75 mbsf the samples are barren of Bolboforma (Table 2).

\section{Site 700}

Hole $700 \mathrm{~B}$ is located in the western region of the East Georgia Basin (Fig. 1 and Table 1). Twenty samples from between 26.81 and 72.17 mbsf were analyzed. The interval between 26.81 and 47.26 mbsf contains Bolboforma eocena, Bolboforma geomaris, Bolboforma indistincta, Bolboforma lamari, and small smooth forms, named Bolboforma sp. B. The strata from 47.26 to 60.15 mbsf are barren of Bolboforma, but the interval between 61.65 and 63.90 mbsf contains a few $B$. indistincta and is, in turn, underlain by sediments barren in Bolboforma down to 72.17 mbsf (Table 3). Spot-checking samples down to lower Eocene strata did not detect any Bolboforma specimens.

\section{Site 702}

Hole $702 \mathrm{~B}$ is located on the central part of the Islas Orcadas Rise (Fig. 1 and Table 1). One sample per section was analyzed for the interval between 26.87 and 108.10 mbsf (44 samples). Down to $75.00 \mathrm{mbsf}$, the samples contain frequent Bolboforma eocena accompanied by mostly rare Bolboforma geomaris, Bolboforma lamari, Bolboforma indistincta, and the small smooth form Bolboforma sp. B, interpreted as cysts of 
Table 2. Distribution of Bolboforma in Hole 699A and correlation to the zonations of planktonic foraminifers (Nocchi et al., this volume) and calcareous nannofossils (Crux, this volume).

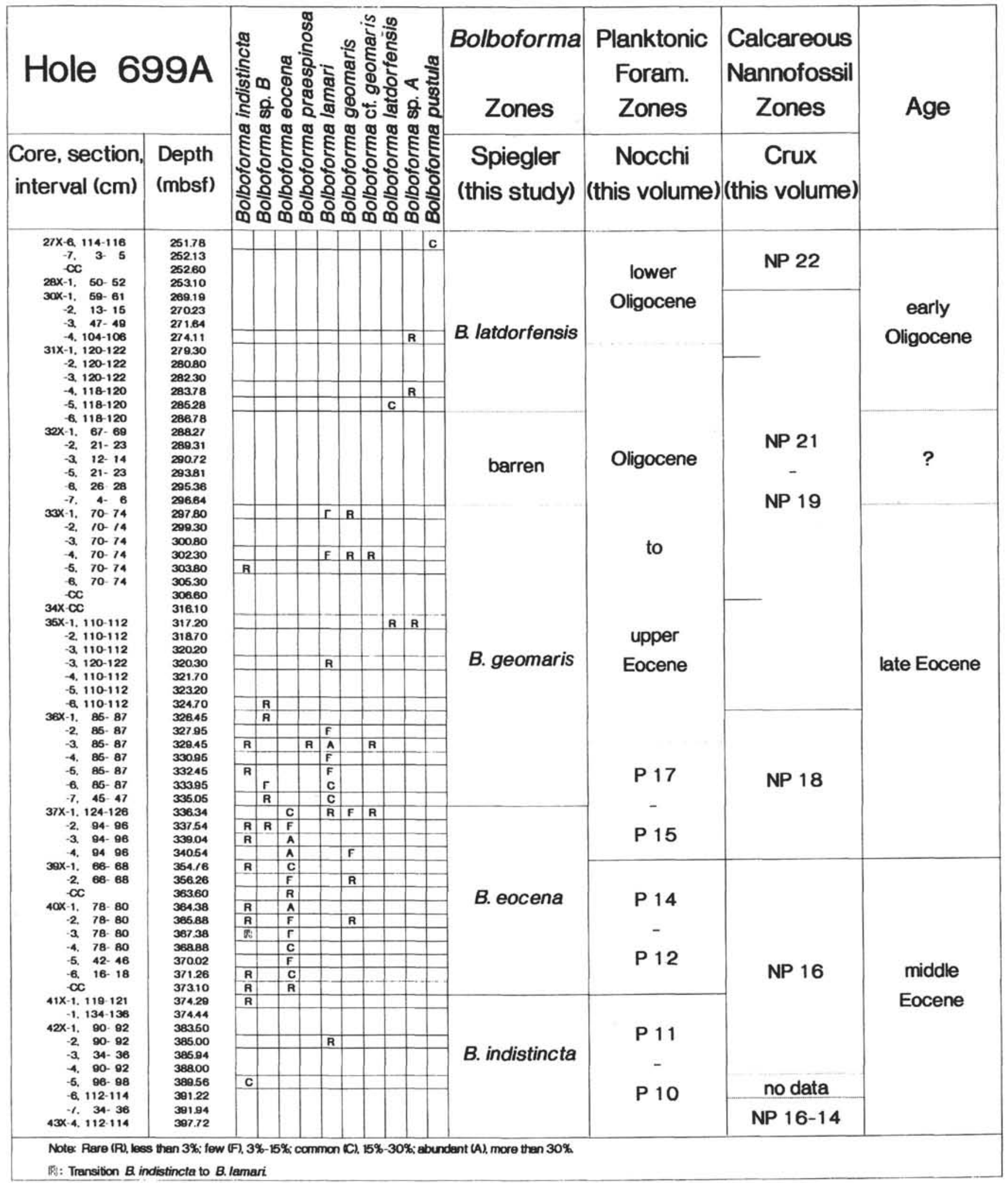


Table 3. Distribution of Bolboforma in Hole $700 \mathrm{~B}$ and correlation to the zonations of planktonic foraminifers (Nocchi et al., this volume) and calcareous nannofossils (Crux, this volume).

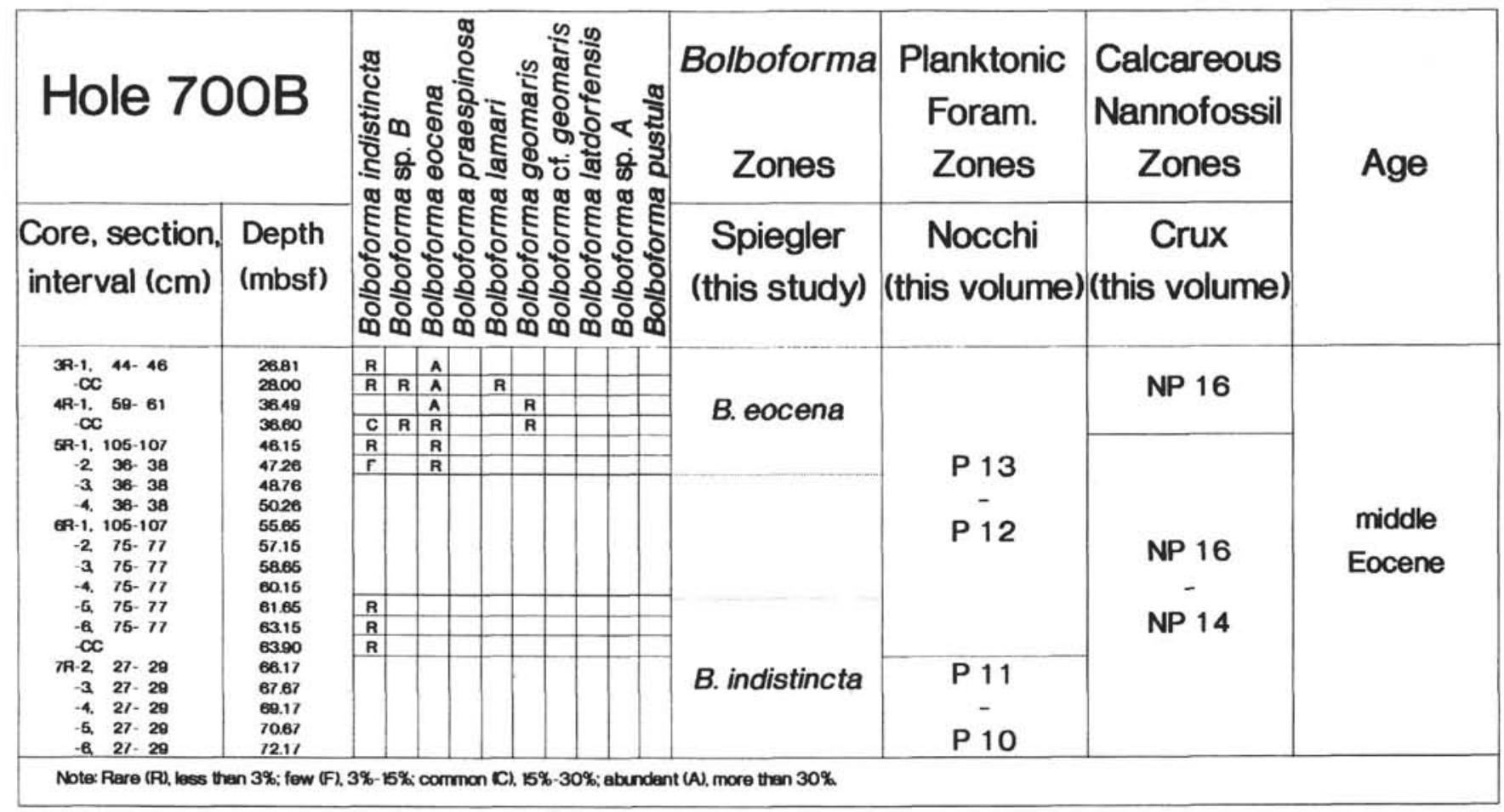

several different Bolboforma taxa. The FO of B. eocena was observed in Sample 114-702B-9X-2, 70-72 cm. Samples down to $96.05 \mathrm{mbsf}$ contain mostly $B$. indistincta. The occurrence of Bolboforma praespinosa in Sections 114-702B-9X-5 and 114$702 \mathrm{~B}-10 \mathrm{X}-1$ to $114-702 \mathrm{~B}-10 \mathrm{X}-2$ is notable, because this species is typical of Eocene strata in the Northern Hemisphere. ${ }^{4}$ The sequence from 97.55 to $108.10 \mathrm{mbsf}$ is barren of Bolboforma (Table 4).

\section{Site $\mathbf{7 0 3}$}

Hole $703 \mathrm{~A}$ is positioned on the Meteor Rise (Fig. 1 and Table 1). The Paleogene sediments from 39.74 to $97.80 \mathrm{mbsf}$ are barren of Bolboforma. Samples down to $110.60 \mathrm{mbsf}$ contain Bolboforma latdorfensis and Bolboforma pustula, both of which are typically Oligocene in age (Spiegler and Daniels, in press). In the samples from deeper than 112.10 mbsf Bolboforma geomaris, Bolboforma lamari, and Bolboforma indistincta are present. The sequence containing $B$. eocena extends from 131.65 to 193.80 mbsf. In Sample 114$703 \mathrm{~A}-23 \mathrm{X}-1,46-48 \mathrm{~cm}$, only $B$. indistincta is present. All underlying samples are barren of Bolboforma (Table 5). A total of 71 samples was examined.

\section{Site 704}

Hole 704B is situated on the central southern part of the Meteor Rise (Fig. 1 and Table 1). Nineteen samples from the interval between 577.32 and 663.90 mbsf were analyzed. Only Samples 114-704B-71X-2, 12-14 cm, and 114-704B-72X-1, 20-22 cm, contain very few Bolboforma sp. A (Table 6), a smooth, broad spherical form that is contained in the lower

\footnotetext{
4 The occurrence of Bolboforma praespinosa is cited from the upper Eocene (NP19/20) Headon Beds, the Isle of Wight, and Emery Down, Lyndhurst, Hampshire, both of which were kindly collected by Dennis Curry/ Itchenor, U.K. (Spiegler and Daniels, in press).
}

Oligocene sequences of Holes 699A and 703A and also in the upper Eocene sediments of the latter.

\section{ZONATION}

The high quality of the Paleogene sediment cores recovered during Leg 114 provided the chance to construct a biostratigraphic zonation by means of Bolboforma. I have divided the Bolboforma-bearing sediments into four Bolboforma zones, spanning the late middle Eocene to early Oligocene. Well-defined species, which are easy to recognize, were chosen to define the zones.

\section{Eocene}

The Eocene sequences were divided by the Bolboforma taxa into three zones: the oldest zone is the Bolboforma indistincta Zone, followed in time by the Bolboforma eocena Zone and Bolboforma geomaris Zone.

\section{Bolboforma indistincta Partial Range Zone}

Age. Early part of late middle Eocene.

Definition. Top: FO B. eocena. Base: FO B. indistincta.

Occurrences. Samples 114-699A-41X-1, 119-121 cm, to 114-699A$42 \mathrm{X}-5,96-98 \mathrm{~cm}$; depth, 374.29 to $389.56 \mathrm{mbsf}$. Samples $114-700 \mathrm{~B}-$ $6 \mathrm{R}-5,75-77 \mathrm{~cm}$, to $114-700 \mathrm{~B}-6 \mathrm{R}-\mathrm{CC}$; depth, 61.65 to $63.90 \mathrm{mbsf}$. Samples 114-702B-9X-3, 70-72 cm, to $114-702 \mathrm{~B}-11 \mathrm{X}-3,125-127 \mathrm{~cm}$; depth, 76.50 to 96.05 mbsf. Samples 114-703A-23X-1, 46-48 cm; depth, 200.80 mbsf.

\section{Bolboforma eocena Total Range Zone}

Age. Late part of late middle Eocene to late Eocene.

Definition. Top: LO B. eocena. Base: FO B. eocena.

Occurrences. Samples 114-699B-37X-1, 124-126 cm, to 114-699B40X-CC; depth, 336.34 to 373.10 mbsf. Samples 114-700B-3R-1, 44-46 cm, to 114-700B-5R-2, 36-38 cm; depth, 26.81 to $47.26 \mathrm{mbsf}$. Samples 114-702B-4X-2, 7-9 cm, to 114-702B-9X-2, 70-72 cm; depth, 26.87 to 75.00 mbsf. Samples $114-703 \mathrm{~A}-15 \mathrm{H}-3,25-27 \mathrm{~cm}$, to $114-$ 703A-22X-CC; depth, 131.65 to 193.80 mbsf. 
Bolboforma geomaris Partial Range Zone

Age. Latest late Eocene.

Definition. Top: upper limit of $B$. geomaris and B. lamari. Base: LO B. eocena.

Occurrences. Samples 114-699B-33X-1, 70-74 cm, to 114-699B$36 \mathrm{X}-7,45-47 \mathrm{~cm}$; depth, 297.80 to 335.05 mbsf. Samples 114-703A-

$13 \mathrm{H}-2,120-123 \mathrm{~cm}$, to $114-703 \mathrm{~A}-15 \mathrm{H}-2,25-27 \mathrm{~cm}$; depth, 112.10 to 130.15 mbsf.

\section{Oligocene}

The Bolboforma latdorfensis Zone characterizes most parts of early Oligocene time.

Bolboforma latdorfensis Partial Range Zone

Age. Early Oligocene.

Definition. Top: unknown. Base: upper limit of B. geomaris and of B. lamari.
Occurrences. Samples 114-699B-27X-6, 114-116 cm, to 114-699B$31 \mathrm{X}-5,118-120 \mathrm{~cm}$; depth, 251.78 to $285.28 \mathrm{mbsf}$. Samples 114-703A$11 \mathrm{H}-6,140-142 \mathrm{~cm}$, to $114-703 \mathrm{~A}-13 \mathrm{H}-1,120-123 \mathrm{~cm}$; depth, 99.30 to 110.60 mbsf. Samples ?114-704B-71X-2, 12-14 cm, to 114-704B-72X1, 20-22 cm; depth, 654.32 to 662.40 mbsf.

Table 7 shows the distribution of the different Bolboforma zones in the Leg 114 holes investigated.

\section{BOLBOFORMA ZONATION AND PALEOMAGNETIC CONTROL}

Available biostratigraphic datums of planktonic foraminifers (Nocchi et al., this volume) and calcareous nannofossils (Crux, this volume) allow identification of magnetozones (Hailwood and Clement, this volume) in the Leg 114 holes. From the cross-correlation of these zones and the absolute ages (proposed by Berggren et al., 1985), it is possible to date the newly established Bolboforma zones approximately.

Table 4. Distribution of Bolboforma in Hole 702B and correlation to the zonations of planktonic foraminifers (Nocchi et al., this volume) and calcareous nannofossils (Crux, this volume).

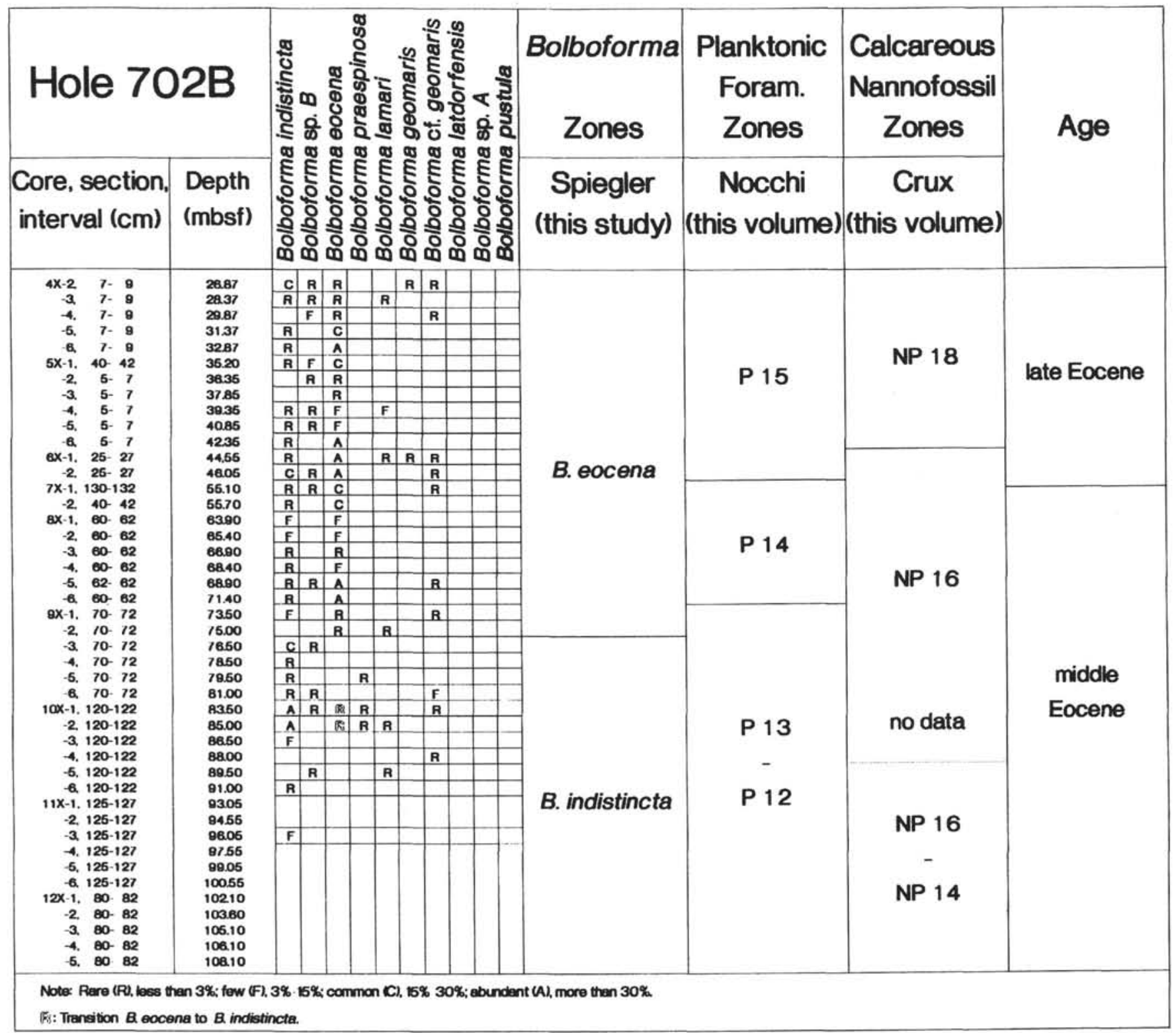


Table 5. Distribution of Bolboforma in Hole 703A and correlation to the zonations of planktonic foraminifers (Nocchi et al., this volume) and calcareous nannofossils (Crux, this volume).

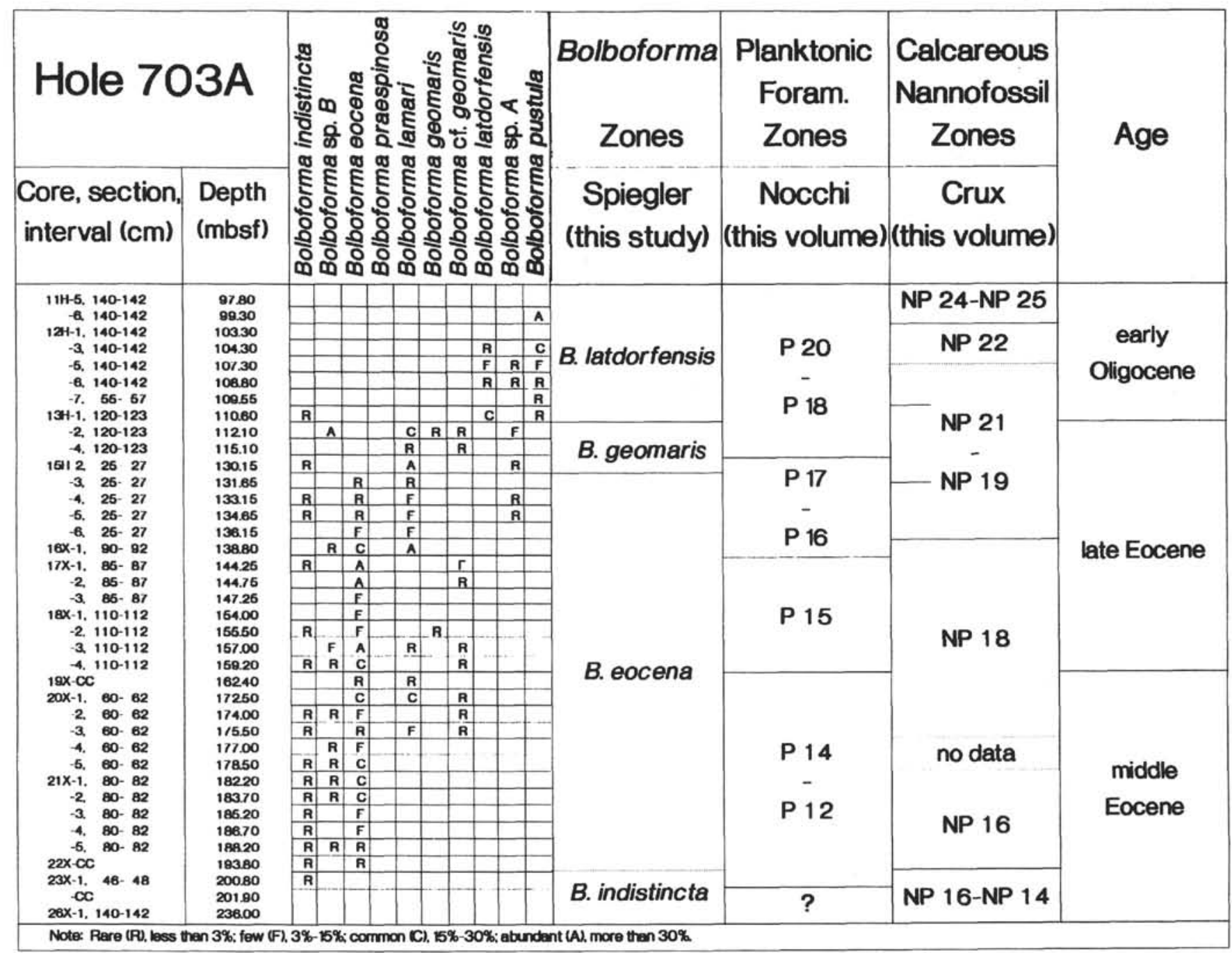

In Hole 699A, Cores 114-699A-42X to $114-699 \mathrm{~A}-27 \mathrm{X}$ contain Bolboforma, but the sediments in Cores 114-699A$46 \mathrm{X}$ to $114-699 \mathrm{~A}-24 \mathrm{X}$ are unsuitable for paleomagnetic analysis because of extensive drilling disturbance and poor core recovery. However, the identification of Chrons C13N and $\mathrm{C} 13 \mathrm{R}$ in the depth interval from 306 to $270 \mathrm{mbsf}$ is possible. Bolboforma latdorfensis is common at $285.28 \mathrm{mbsf}$, dated by the paleomagnetic control as $\sim 36 \mathrm{Ma}$. The LO of Bolboforma geomaris and Bolboforma lamari at $297.80 \mathrm{mbsf}$ falls into Chron C13R at the postulated Eocene/Oligocene boundary.

In Hole 700B the middle Eocene sequence from 63.90 to 26.81 mbsf contains Bolboforma, but downhole contamination in the upper $270 \mathrm{~m}$ of the record prevents paleomagnetic analysis.

In Hole 702B the Bolboforma indistincta and the Bolboforma eocena Zones are present. The B. indistincta Zone extends from Samples 114-702B-11X-3, 125-127 cm, to 114 $702 \mathrm{~B}-9 \mathrm{X}-3,70-72 \mathrm{~cm}$, and the younger $B$. eocena Zone from Samples 114-702B-9X-2, 70-72 cm, up to 114-702B-4X-2, 7-9 $\mathrm{cm}$. The magnetostratigraphic record in Cores 114-702B-13X to $114-702 \mathrm{~B}-8 \mathrm{X}$ is well defined with Chrons $\mathrm{C} 20 \mathrm{R}$ to $\mathrm{C} 18 \mathrm{~N}$. The paleomagnetic shift from $\mathrm{C} 20 \mathrm{~N}$ to $\mathrm{C} 19 \mathrm{R}$, dated as $44.7 \mathrm{Ma}$ according Berggren et al. (1985), is documented in the lower part of Core 114-702B-11X. In Sample 114-702B-11X-3, 125-
$127 \mathrm{~cm}$, the $\mathrm{FO}$ of $B$. indistincta lies approximately $250 \mathrm{~cm}$ higher in the sequence and, thus, according to the sedimentation rate during this period of $12 \mathrm{~m} / \mathrm{m}$.y. (Ciesielski, Kristoffersen, et al., 1988), it is 0.2 Ma younger than the C20N/C19R shift. $B$. indistincta is the stratigraphically oldest known Bolboforma taxon. For this reason, the presently known first appearance of the genus Bolboforma can be dated as approximately $44.5 \mathrm{Ma}$. The boundary between the $B$. indistincta Zone and the B. eocena Zone lies between Samples 114-702B$9 \mathrm{X}-3,70-72 \mathrm{~cm}$, and 114-702B-9X-2, 70-72 cm. The paleomagnetic shift between C18R and C18N dated as $42.7 \mathrm{Ma}$ is documented between Cores 114-702B-9X and 114-702B-8X. Consequently, the boundary between the $B$. indistinct $a$ and $B$. eocena Zones can be equal to $\sim 43 \mathrm{Ma}$. The $B$. eocena Zone extends up to Sample 114-702B-4X-2, 7-9 cm. The upper half of Core 114-702B-4X is correlated with Chron C16N (38.1 to $39.2 \mathrm{Ma}$ ). Therefore, the LO of B. eocena in Hole 702B is younger than $39.2 \mathrm{Ma}$ and older than $38.1 \mathrm{Ma}$.

In Hole $703 \mathrm{~A}$ the zones of B. indistincta (Sample 114702B-23X-1, 46-48. cm; $200.80 \mathrm{mbsf}$ ), B. eocena (193.80 to $131.65 \mathrm{mbsf}$ ), B. geomaris (130.15 to $112.10 \mathrm{mbsf}$ ), and $B$. latdorfensis ( 110.60 to $99.30 \mathrm{mbsf}$ ) are present. Beneath 115 mbsf, drilling disturbance and/or poor recovery of the se- 
Table 6. Distribution of Bolboforma in Hole 704B and correlation to the zonations of planktonic foraminifers (Nocchi et al., this volume) and calcareous nannofossils (Crux, this volume).

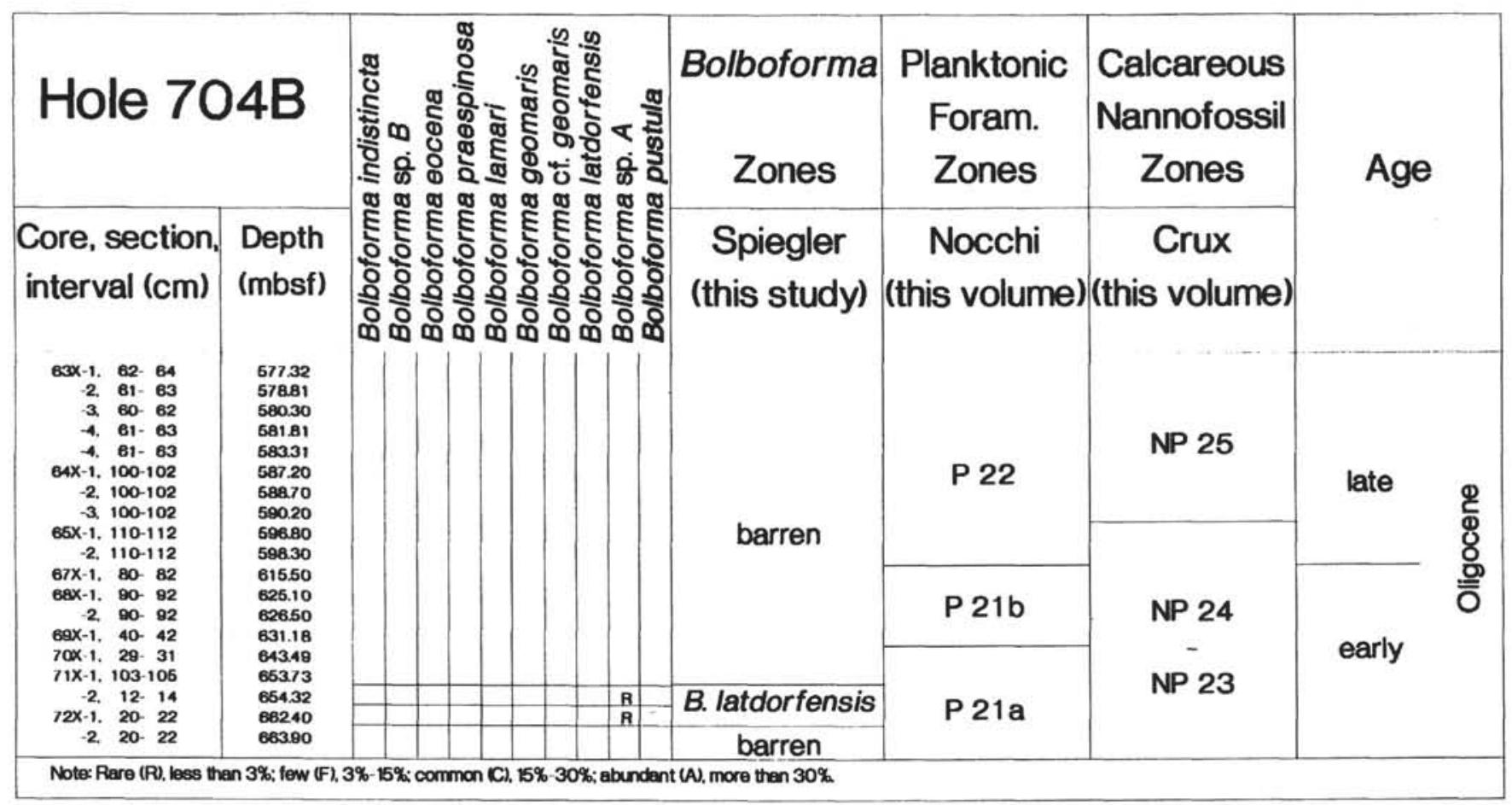

Table 7. Zonation of Bolboforma in Leg 114 holes investigated.

\begin{tabular}{lccccc}
\hline & \multicolumn{5}{c}{ Depth (mbsf) } \\
\cline { 2 - 6 } $\begin{array}{l}\text { Bolboforma } \\
\text { zone }\end{array}$ & $\begin{array}{c}\text { Hole } \\
699 \mathrm{~A}\end{array}$ & $\begin{array}{c}\text { Hole } \\
700 \mathrm{~B}\end{array}$ & $\begin{array}{l}\text { Hole } \\
702 \mathrm{~B}\end{array}$ & $\begin{array}{c}\text { Hole } \\
703 \mathrm{~A}\end{array}$ & $\begin{array}{c}\text { Hole } \\
704 \mathrm{~B}\end{array}$ \\
\hline $\begin{array}{l}\text { B. latdorfensis } \\
\text { B. geomaris }\end{array}$ & $251.78-285.28$ & & & $99.30-110.60$ & $654.32-662.40$ \\
$\begin{array}{l}\text { B. eocena } \\
\text { B. indistincta }\end{array}$ & $336.34-335.05$ & & & $112.10-130.15$ & \\
\hline
\end{tabular}

quence prevent paleomagnetic analysis. Only the $\mathrm{C} 15 \mathrm{~N}(?) /$ C13R datum (37.24 Ma) is well documented, between 85 and $75 \mathrm{~cm}$ in Section 114-703A-15H-2 (130.75 and $130.65 \mathrm{mbsf}$, respectively) (Hailwood and Clement, this volume). This date falls between samples at 131.65 and 130.15 mbsf, which document the boundary between the B. eocena and $B$. geomaris Zones. In comparison with Hole 699A, parts of the B. geomaris Zone seem to be missing from Hole 703A. The next well-established paleomagnetic datum is the $\mathrm{C} 12 \mathrm{R} /$ $\mathrm{C} 12 \mathrm{~N}$ shift $(32.90 \mathrm{Ma})$ at $95.74 \mathrm{mbsf}$, which lies in a sequence barren of Bolboforma.

Sediments from Cores 114-704B-71X to 114-704B-72X contain Bolboforma, but no paleomagnetic data are available.

According to previously mentioned datums it is possible to date approximately the zones defined here:

$\sim 36 \mathrm{Ma}$ - base of $B$. latdorfensis Zone

$>38.1-<39.2 \mathrm{Ma}-$ base of $B$. geomaris Zone

$\sim 43.0 \mathrm{Ma}$-base of $B$. eocena Zone

$\sim 44.5 \mathrm{Ma}$-base of $B$. indistincta Zone.

\section{CONCLUSIONS}

1. Bolboforma taxa are present in Paleogene sediments of the subantarctic Atlantic. The stratigraphic range of Bolboforma extends down into the middle Eocene.
2. The results of Bolboforma analysis of ODP Leg 114 Holes 699A, 700B, 702B, 703A, and 704B enable us to establish a fourfold biostratigraphic zonation from the late middle Eocene to early Oligocene.

3. The Bolboforma zones are correlated to the paleomagnetic record and dated for approximate age.

\section{ACKNOWLEDGMENTS}

I thank Dr. Juliane Fenner, Geologisch-Paläontologisches Institut und Museum der Universität Kiel, for providing some Leg 114 core-catcher samples for the first check of Bolboforma evidence.

Sincere thanks are due to Dr. Marisa Nocchi, Dipartemento di Scienze Terra dell'Universita Perugia (Italia), for making available all the Leg 114 washed residues of planktonic foraminifer samples and for her hospitality in Perugia.

I thank Dr. A. Mackensen, AWI-Bremerhaven (Germany), for discussions concerning the taxa.

SEM pictures were taken at Geologisch-Paläontologisches Institut und Museum der Universität Kiel. I thank U. Schuldt, A. Munnecke, D. Meinhold, and U. Grützmacher for their technical assistance. 


\section{REFERENCES}

Berggren, W. A., Kent, D. V., Flynn, J. J., and Van Couvering, J., 1985. Cenozoic geochronology. Geol. Soc. Am. Bull., 96:14071418.

Ciesielski, P. F., Kristoffersen, Y., et al., 1988. Proc. ODP, Init. Repts., 114: College Station, TX (Ocean Drilling Program).

Daniels, C. H. von, and Spiegler, D., 1974. Bolboforma n. gen. (Protozoa?) - eine neue stratigraphisch wichtige Gattung aus dem Oligozän/Miozän Nordwestdeutschlands. Paleontol. Z., 48:57-76.

Daniels, C. H. von, Spiegler, D., and Bijvank, G., 1981. Zweikammerige Bolboforma (Mikroproblematika, Protozoa ?). Paleontol. Z., 55:175-177.

Echols, D. J., 1985. "Bolboforma": a Miocene algae(?) of possible biostratigraphic and palaeoclimatic value. In Bougault, H., Cande, S. C., et al., Init. Repts. DSDP, 82: Washington (U.S. Govt. Printing Office), 605-610.

Gazdzicki, A., and Wrona, R., 1986. Polskie badania paleontologiczne w antarktyce zachodniej (1986). Przeglad Geol., 34,11(403):609-617.

Kennett, D. M., and Kennett, J. P., in press. Bolboforma Daniels and Spiegler, from Eocene and lower Oligocene sediments, Maud Rise, Antarctica. In Barker, P. F., Kennett, J. P., et al., Proc. ODP, Sci. Results, 113: College Station, TX (Ocean Drilling Program).

Leg 114 Scientific Drilling Party, 1987. Leg 114 finds complete sedimentary record. Geotimes, 32:23-25.

Mackensen, A., and Spiegler, D., 1989. A new Bolboforma (Algae, Chrysophyseae?) from the late Eocene of the southern Indian Ocean, Ocean Drilling Program Leg 120. In Schlich, R., Wise, S. W., Jr., et al., Proc. ODP, Init. Repts., 120: College Station, TX (Ocean Drilling Program), 71-72.

McNeil, D. H., 1988. New occurrence of the algal cyst Bolboforma badenensis Szczechura in the Miocene of the Beaufort Sea, Arctic Canada. Micropaleontology, 34:90-96.

Müller, C., Spiegler, D., and Pastouret, L., 1984. The genus Bolboforma Daniels and Spiegler in the Oligocene and Miocene sediments of the North Atlantic and northern Europe. In de Graciansky, P. C., Poag, C. W., et al., Init. Repts. DSDP, 80: Washington (U.S. Govt. Printing Office), 669-675.

Murray, J. W., 1979. Cenozoic biostratigraphy and paleoecology of Sites 403 to 406 based on the foraminifers. In Montadert, L.,
Roberts, D. G., et al., Init. Repts. DSDP, 48: Washington (U.S. Govt. Printing Office), 415-430. 1984. Biostratigraphic value of Bolboforma, Leg 81, Rockall Plateau. In Roberts, D. G., Schnitker, D., et al., Init. Repts. DSDP, 81: Washington (U.S. Govt. Printing Office), 535-539.

1987. Bolboforma from North Atlantic sites, Deep Sea

Drilling Project Leg 94. In Ruddiman, W. F., Kidd, R. B., Thomas, E., et al., Init. Repts DSDP, 94: Washington (U.S. Govt. Printing Office), 813-814.

Pallant, A., and Kaminski, M., 1989. Bolboforma from Leg 105, Labrador Sea and Baffin Bay, and the chronostratigraphy of Bolboforma in the North Atlantic. In Srivastava, S. P., Arthur, M. A., et al., Proc. ODP, Sci. Results, 105: College Station, TX (Ocean Drilling Program), 381-385.

Poag, C. W., and Karowe, A. L., 1986. Stratigraphic potential of Bolboforma significantly increased by new finds in the North Atlantic and South Pacific. Palaios, 1:162-171. 1987. Bolboforma (Chrysophyta?) from the western North Atlantic. In Poag, C. W., Watts, A. B., et al., Init. Repts. DSDP, 95: Washington (U.S. Govt. Printing Office), 429-438.

Qvale, G., and Spiegler, D., 1989. The stratigraphic significance of Bolboforma (Algae, Chrysophyta) in Leg 104 samples from the Vøring Plateau. In Eldholm, O., Thiede, J., et al., Proc. ODP, Sci. Results, 104: College Station, TX (Ocean Drilling Program), 487-495.

Rögl, F., and Hochuli, P., 1976. The occurrence of Bolboforma, a probable algal cyst, in the antarctic Miocene of DSDP Leg 35. In Hollister, C. D., Craddock, C., et al., Init. Repts. DSDP, 35: Washington (U.S. Govt. Printing Office), 713-719.

Spiegler, D., 1987. Encapsulated Bolboforma (Algae, Chrysophyta) from late Miocene deposits in the North Atlantic. Meded. Werkgroup Tertiaire Kwartaire Geol., 24:157-166.

Spiegler, D., and Daniels, C. H. von, in press. A stratigraphic and taxonomic atlas of Bolboforma (Protophyses, Incertae Sedis, Tertiary). J. Foraminiferal Res.

Tappan, H., 1980. The Paleobiology of Plant Protists: San Francisco (W. H. Freeman).

Date of initial receipt: 14 March 1989

Date of acceptance: 27 October 1989

Ms 114B-132 


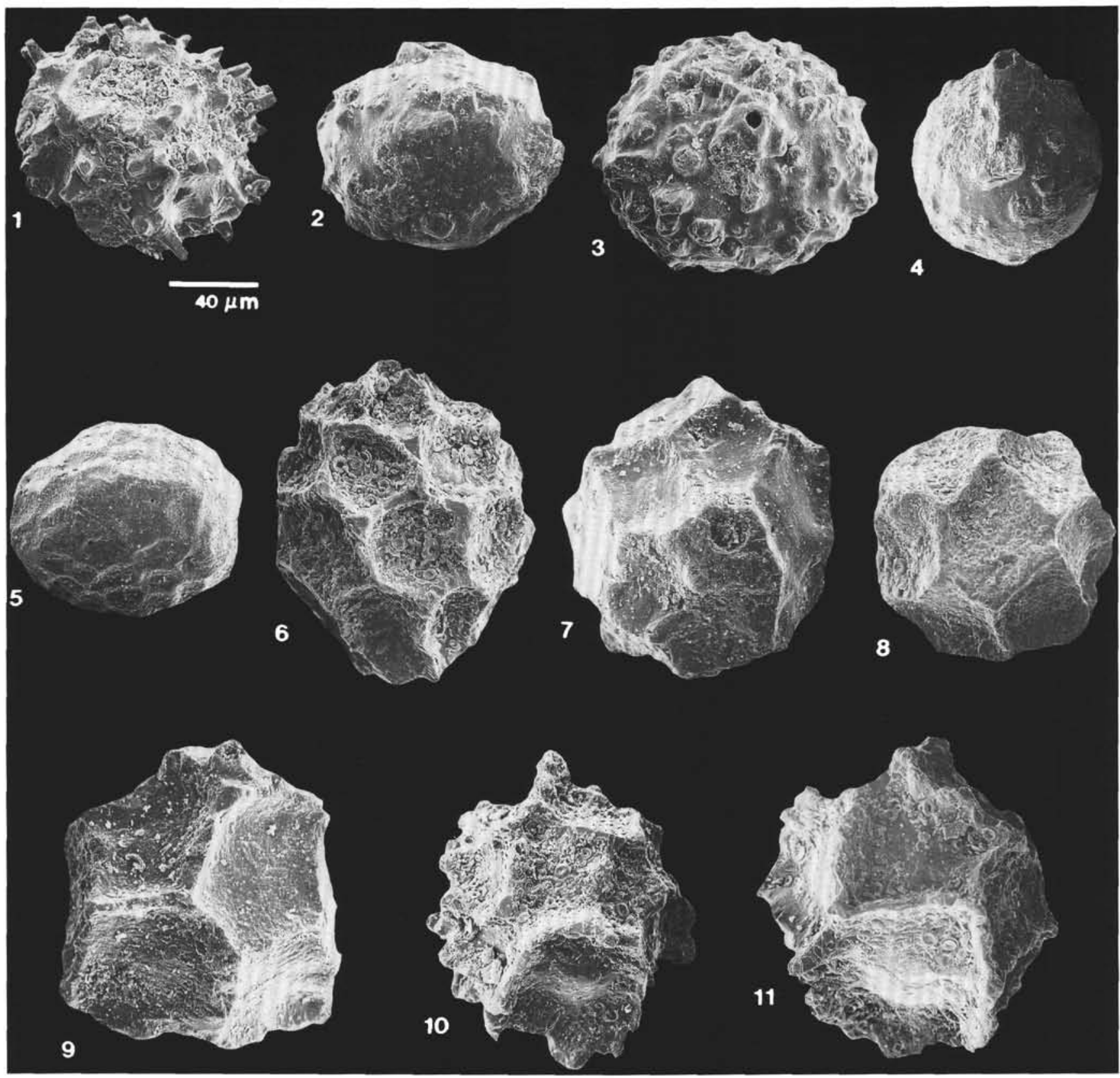

Plate 1. Bolboforma, Leg 114. 1. Bolboforma latdorfensis Spiegler, in press. Empty spheroid outer test, coarsely reticulated and ornamented by long irregularly arranged spines. Sample 114-699A-31X-5, 118-120 cm. 2-4. Bolboforma pustula Spiegler, in press. Empty spheroid bipolarly flattened test with irregularly arranged blunt spines. 2, 3. Sample 114-699A-27X-6, 114-116 cm; 4. Sample 114-703A-13H-1, 120-123 $\mathrm{cm}$. 5. Bolboforma sp. A. Spheroid bipolarly flattened test, smooth or ornamented by weak reticulations (cyst?). Sample 114-699A-30X-4, 104-106 cm. 6, 7. Bolboforma geomaris Spiegler, in press. Empty elongated test ornamented by five to eight reticulations in equatorial diameter, no spines. 6. Sample 114-703A-13H-2, 120-123 cm; 7. Sample 114-699A-33X-4, 70-74 cm. 8, 9. Bolboforma cf. geomaris Spiegler, in press. Very coarse reticulated with three to four reticulations in equatorial as well as polar diameter 8. Sample 114-703A-20X-1, 60-62 cm; 9. Sample 114-699A-33X-4, 70-74 cm. 10, 11. Bolboforma lamari Mackensen and Spiegler, 1989. Empty pear-shaped test with coarse reticulation. Knobs and spines of different length are situated on the ridges. The aboral part of the test is bordered by a circular thickening with spines. Sample 114-703A-13H-2, 120-124 cm. 


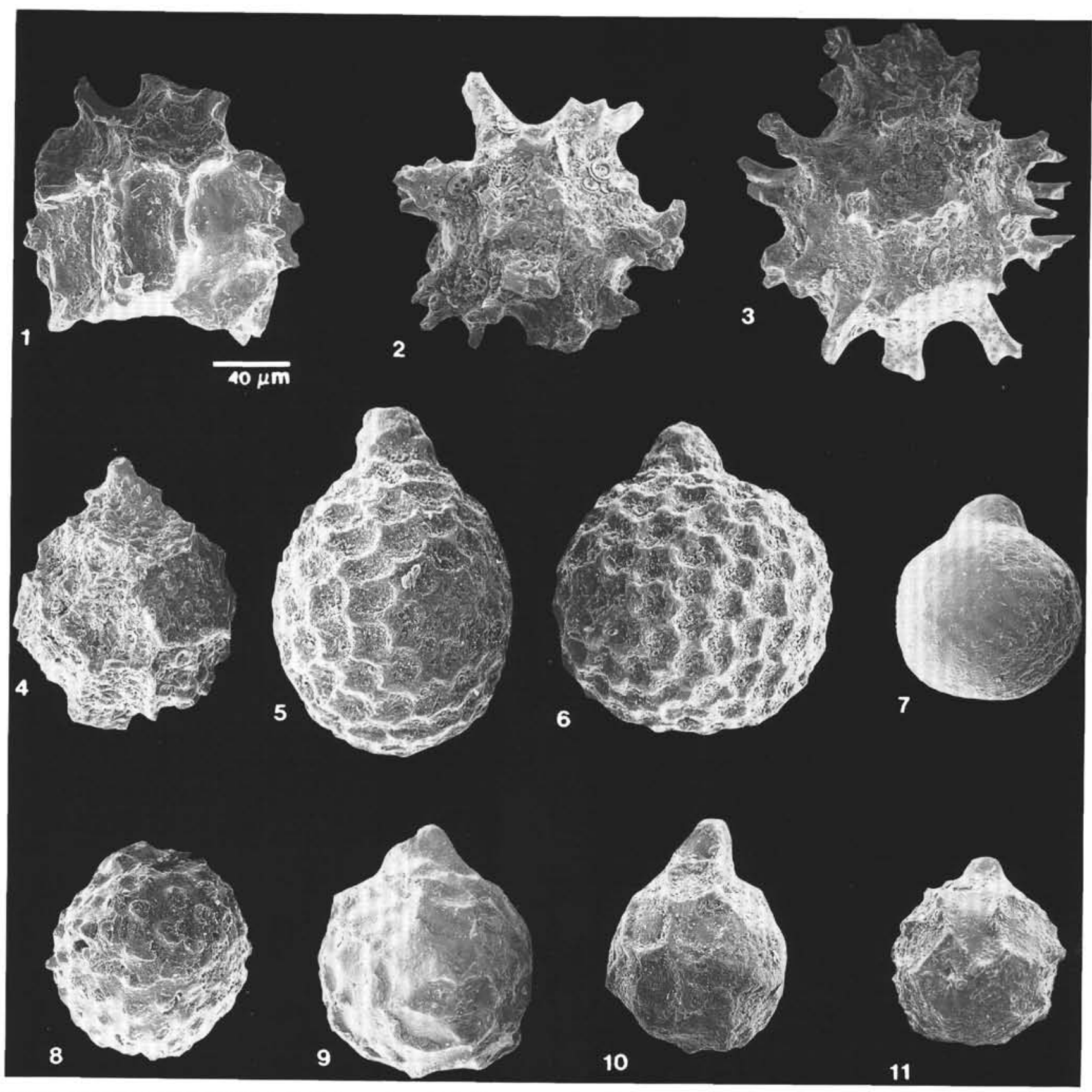

Plate 2. Bolboforma, Leg 114. 1-3. Bolboforma lamari Mackensen and Spiegler, 1989. 1. Sample 114-699A-36X-6, 85-87 cm; 2. Sample 114-703A-19H-CC; 3. Sample 114-699A-36X-7, 45-47 cm. 4. Transitional form between Bolboforma indistincta and Bolboforma lamari. Sample 114-699A-40X-3, 78-80 cm. 5, 6. Bolboforma eocena Spiegler, in press. Empty spheroid to elongated test with a pronounced thick neck, ornamented by fine reticulations. 5. Sample 114-703A-17X-2, 85-87 cm; 6. Sample 114-703A-18X-3, 110-120 cm. 7. Bolboforma sp. B. Small smooth test with a thick neck (cyst?). Sample 114-699A-36X-7, 45-47 cm. 8. Bolboforma praespinosa Spiegler, in press. Small spheroid test ornamented by regularly arranged blunt spines. Sample 114-699A-36X-3, 85-87 cm. 9-11. Bolboforma indistincta Spiegler, in press. Spheroid test with a pronounced thick neck and ornamented by indistinct reticulations. 9. Sample 114-699A-42X-5, 96-98 cm; 10. Sample 114-703A-21X-1, 80-82 cm; 11. Sample 114-699A-40X-2, 78-80 cm. 